\author{
Zh.Zh. Sherizatova \\ Karagandy University of the name of E.A. Buketov, Kazakhstan \\ (E-mail: zh.sher@mail.ru)
}

\title{
Lexical phrases with anthroponymic components in medical terminology
}

\begin{abstract}
This article analyzes anthroponymic component language chunks in medical terminology. The research focuses on a large group of medical fixed phrases containing anthroponyms in their component composition. The main attention is paid to structural, semantic and etymological analysis. The basic lexical sets of anthroponymic component language chunks have been distinguished. The main sources and models of lexical phrases used in the formation of medical terms have been defined. The collected material allows us to state that the words syndrome, symptom and disease, being the structural core of medical phraseological units, are often distinguished in the phraseological units analyzed. The dependent component in a noun phrase is represented by an anthroponym. As a rule, this is the name of the scientist who made important discoveries in the medical field. Much attention is paid to the proper name semantics as part of a phraseological unit. Based on the etymological analysis of the material under study, the classification of medical phraseological units with a proper name component has been developed. The analysis showed that the origin of phraseological units with a proper name is based on real personalities, scientists, ancient and biblical mythology, literary works associated with the names of characters. Phraseological combinations associated with national and cultural specifics are of outstanding interest for linguistic analysis. The study showed that a proper name is a special linguistic sign that involves ethnic culture. The article discusses lexical chunks formed by metaphorical transfer in detail. The metaphorical transfer of names in the terminological system is noticed regularly, which is due to the constant development of medical terms' new names and meanings formation through the scientific rethinking of common words.
\end{abstract}

Keywords: anthroponym, phraseological unit, component, syndrome, symptom, medical terminology.

In linguistic studies, special attention is paid to medical phraseology, which has a long history of formation, but at the same time is relevant and continues to develop rapidly. In the context of the modern scientific anthropocentric paradigm, the problem of linguocultural analysis of medical phraseology is of great scientific interest. The relevance of the topic is determined by its importance for linguistic and cultural studies based on modern achievements of linguistic science.

The source of the language material was the Dictionary of Medical Terms, edited B.V. Petrovsky. 6047 phraseological units were selected by the method of continuous sampling from the indicated medical terminological source, the basis of the catalogue is made up of numerous phraseological units with anthroponyms [1; 464].

As it is known, research in the field of phraseological systems are of great theoretical and practical importance, far beyond the scope of modern linguistics. The most famous fundamental works of scientists on questions of phraseological units are connected with the names of V.V. Vinogradov, N.M. Shansky, V.N. Telia, A.V. Kunin and many others etc. In the works of modern linguists, questions of phraseological units in the linguoculturological aspect are examined on the basis of various language systems (V.M. Mokienko, A.I. Fedorov, M.K. Pak and others). In linguistic science, there is an increasing interest in the problem of terminological phraseology in the context of linguoculturology (E.V. Smirnova, E.M. Kakzanova, M.V. Ozingin, and many others).

Medical lexical phrases are one of the most striking manifestations of the national-cultural specificity of the language, they reflected numerous linguistic cultures, they contain a different cultural and ethnic component in their meaning.

Medical phraseological units with anthroponymic components are a special linguistic sign that represents national-cultural specificity, since it is these units that largely reflect the history, culture, traditions and mentality of the people. The national-cultural specificity of medical phraseological units with an anthroponym component is an important linguistic sign with special cultural potential.

The phraseological composition of medical terminology is very extensive and diverse, it is dynamically replenished, constantly enriched due to the development of medical science. Famous linguist A.V. Kunin accurately noted that «the most important source of phraseological units is professional speech» $[2 ; 112]$. 
Medical terminological phraseological units are an indivisible combination of two or more independent words. The most productive components in the formation of medical lexical phrases are anthroponyms, which is a common way of forming terminological nominations. Anthroponymic lexical phrases are most interesting in terms of education and structural and semantic identity. Our analysis of phraseological units with anthroponyms from the point of view of structure showed that nominal combinations are the most frequent. For example, Wilson's lichen, Ivanov's muscle, Ludwig's angina, etc. As a rule, the surname is given, more rarely, the name of the scientist. Among the structural models by which medical lexical phrases are built, the noun is an integral component of all phrases, where it can be the main or dependent word.

Such activity of a noun testifies to its semantic capacity. Most medical lexical phrases are considered to be substantive phrases, the core component of substantive phraseological units is a noun.

It should be noted that the main and most common structural model is the combination of a noun in Nominative Case with a noun in Genitive Case. For example, Litre's hernia, Todd's paralysis, Friedreich's foot, etc. In this model of collocations, the anthroponym acts as a dependent component that reflects the basic concept of terminological phraseology, i.e. It is its semantic core, and at the same time indicates the medical origin of this phraseological unit, and also is its structural core. Our observations showed that the phrases of this model are frequency and widely used.

A significant part of lexical phrases of terminological origin in its structure consists of two components: Baker's cyst, Delbe bandage, Corrigen's pulse, etc. We also noted phraseological units that consist of three components, for example, Abramov-Fiedler myocarditis, Brave-Jackson epilepsy, a symptom of Obukhov hospital and etc.; and four components: Adams-Morgagni-Stokes syndrome, Abta Letterera-Siwe disease, Alice in Wonderland syndrome, etc. In this case, combinations of anthroponyms are widely represented - the names of two and three scientists who are the discoverers who described the medical phenomenon.

The collected material allows us to state that the words syndrome, symptom, disease, which are both the semantic and the structural core of medical phraseological units, are often noted in the analyzed phraseological units. The dependent component in the phrase is represented by an anthroponym, as a rule, this is the name of the scientist who made important discoveries in the field of medicine. The analyzed material can be classified into the following groups:

1) phraseological units with a component of the syndrome;

2) phraseological units with a symptom component;

3) phraseological units with a component of the disease.

The most common are lexical phrases with the component- syndrome. In medical terminology the statistical counting (583 phraseological units) shows the quantity and wide functioning of phraseological units with a noun syndrome. For example, Avellis syndrome, Balzer syndrome, Weber syndrome, Glaser syndrome, Jacques syndrome, Oppel syndrome, Charlin syndrome, etc.

The presence of a large number of examples with a noun syndrome is not accidental, since in the medical professional field it is the main and most common word. The lexeme syndrome has firmly entered the medical phraseology from the Greek language (syndrome - confluence) and means «a set of symptoms combined by a single pathogenesis; sometimes this term refers to independent nosological units or stages of a disease». For example, Balzer syndrome means «pancreatic fatty necrosis in acute hemorrhagic pancreatitis», first described in the nineteenth century by German physician V. Balzer.

In modern medical speech, the sphere of use of lexical phrases with a component of the syndrome is constantly expanding. It should be noted that many lexical phrases with the components of the syndrome and symptom are used not only in the direct sense, but also in the figurative meaning, such lexical phrases are quite common in modern Russian language. It is important to note that such figurative expressions created on the basis of biblical and mythical characters, names of literary heroes, great creative personalities, and surnames of patients were included in medical phraseology. In phraseological units, various associative concepts related to medicine are reflected. This can be seen in such expressions as, for example: Alice in Wonderland syndrome (by the name of a character in a famous fairy tale), Harlequin's syndrome (by the character of the Italian «comedy of masks» who wore a costume of colorful patches), Van Gogh's syndrome (by the name of a Dutch patient artist of the nineteenth century Van Gogh), Munchausen syndrome (by the name of a character in a literary work) - «mental disorder, expressed in a continuous stream of implausible complaints about health, painful, tearing the whole body pain, often with infusion good demands to perform abdominal surgery to eliminate them». These anthroponyms are formed by metaphorization, by analogy. To create imagery, characters that are well-known to the people who have their own specific features in terms of content and expression are usually used, they reflect the estimated state of a person. 
For example, a lexical phrase of Alice in Wonderland syndrome is formed by association with the name of the famous novel by the English writer Lewis Carroll, where the main character Alice experienced conditions similar to the symptoms of this syndrome - hallucinations, inadequate estimation of the shape and size of objects. Most lexical phrases refer to mental and neurological disorders, symptoms and syndromes similar to the sensations, phobias and disorders experienced by literary characters. This phraseologism is formed by a method of metaphorization, by analogy with the heroine of world classical literature. The analyzed material allows us to state that metaphorical transfer is characteristic and typical of a number of groups of medical lexical phrases with anthroponymic components. The productivity of metaphorical transformation in medical terminology is explained, in our opinion, in the desire to express thoughts in other understandable, vivid forms, to find appropriate linguistic means.

The next in frequency of functioning is the symptom component in the composition of nominal phrases. So, in our catalogue there are 503 phraseological units. For example, a symptom of Buddha, a symptom of Strauss, a symptom of de Musset etc. The word symptom means "a specific symptom of a disease, a manifestation of a disease," it entered into medical terminology from the Greek language. A feature of the semantics of the word symptom is that it can only be used as a part of medical phraseological units. For example, a symptom of de Musset (after the sick French poet and playwright of the nineteenth century. Alfred de Musset) is «head-to-back swaying synchronized with the rhythm of the heart; a sign of aortic valve insufficiency due to a sharp change in the blood supply to the arteries of the head», Phraseological expression of Green's symptom is named after an American doctor who described the signs of heart failure, etc.

The third group of terminological phraseological units is represented by nominations with a disease token. Our catalogue has 222 lexical phrases. For example, Alzheimer's disease, Becker's disease, Downey's disease, etc.

The word disease means «violation of the normal functioning of the body» as a part of phraseology, has a special function, since one of the most important signs of this token is associated with various clinical pathologies. The main specialists in the disease are doctors who, based on the symptoms of the disease, make a diagnosis. The component of the disease, which is part of phraseological combinations, gives the general name of specific nosological units. For example, the phraseological expression Addison's disease is named after the English doctor Thomas Addison, thanks to whom the pathological state of endocrine disease was first described in medicine. A lexical phrase Bekhterev's disease is named after a Russian scientist, a doctor who described inflammation of the intervertebral joints.

Medical phraseologisms were formed in the process of centuries of human study of the world around them, they have their own specific features in terms of origin and content, as they are international. As it is known, in various forms of folk culture - in rituals, beliefs, traditions, in folk medicine - medical phraseologisms are reflected. Their development is closely connected with the history and culture of the people, which are manifested in its phraseological composition, since phraseology has always been and remains a reliable source of information about the mentality and culture of the people. According to V.A. Maslova, «phraseological units, reflecting in their semantics the long process of development of the culture of the people, fix and pass on cultural settings and stereotypes, standards and archetypes from generation to generation» $[3 ; 43]$.

In our opinion, the classification of phraseological units with a proper name by their origin seems to be interesting. We distinguish four groups:

1) phraseological units associated with the names of Western European and Russian scientists;

2) phraseological units associated with ancient Greek scholars;

3) phraseological units associated with mythology;

4) biblical phraseological units.

The first group consists of phraseological units of terminological origin, borrowed from Western European languages. As a rule, anthroponyms are associated with English, French, American, German scientists who have made a tremendous contribution to the development of medical science. Medical lexical phrases with anthroponymic components are certainly international, for example, Koch's wand, Quincke's edema, Parkinson's disease, Stokes collar, Todd's paralysis, Azelli's vessels, Burkitt's lymphoma, Vergi's cyst, Herbazi anemia, etc.

The lexical phrase Corvisart's facial is named after the French therapist J.N. Corvisar, who first described and characterized the symptoms of severe chronic heart disease; the phraseologism Parkinson's disease owes its origin to the English physician and author of Essay on tremor palsy, James Parkinson. The phraseological combination of the Stokes collar arose as a result of the description of the symptoms of 
neck edema by the Irish doctor William Stokes «swelling of the neck, and sometimes of the face and hands, upper chest and shoulder blades, accompanied by swelling of the skin veins; sign of compression of the superior vena cava»; the emergence of a lexical phrase of Quincke edema is associated with the name of the famous German doctor Heinrich Quincke, who first described an allergic disease. The phrase Green's symptom is named after an American doctor who described the signs of heart failure.

The first group also includes medical phraseological units associated with the names of Russian scientists: Alferov's operation, Botkin's disease, Sklifosovsky's Russian castle, and others. The real names of the doctors who became famous for inventing the means for treating certain diseases are reflected in lexical phrases. For example, a lexical phrase of epidemic hepatitis is better known as Botkin's disease, named after a Russian doctor and scientist who first suggested that hepatitis results from some kind of infection. In honor of this discovery, epidemic hepatitis began to be called Botkin's disease, despite a large synonymous series. The operation that later became known as the Russian castle or Sklifosofsky's castle, named after the Russian surgeon, who proposed a method for joining the length of tubular bones, which made it possible to firmly fix the bones with a false joint of the thigh and shoulder, is known worldwide. The lexical phrase of ankylosing spondylitis is named after a Russian scientist, a doctor Bekhterev who described inflammation of the intervertebral joints: «a disease from the group of collagenoses, characterized by a primary lesion of the articularligamentous apparatus of the spine (often limbs), as well as involvement of internal organs (heart, aorta, kidneys)); is prone to a chronic progressive course with the development of ankylosis». The lexical phrase Vishnevsky ointment is widely known. The origin of phraseology is associated with the name of the Russian scientist A.A. Vishnevsky, who first showed the healing effect of dressings with oil-balsamic emulsion in the treatment of suppurating gunshot wounds. The people name this emulsion was fixed as Vishnevsky ointment.

The second group of phraseological units is associated with Ancient Greece, which played a huge role in the development of medical terminology and left an indelible mark on science. A significant contribution to the development of terminology was made by the reformer of ancient medicine Hippocrates. The source of enrichment of medical phraseology is the discoveries of Hippocrates, which are fixed in lexical phrases and are included in the language fund of scientific vocabulary. Many medical expressions are associated with the name of Hippocrates: the Hippocratic oath, the face of Hippocrates, the mask of Hippocrates, the fingers of Hippocrates, the nail of Hippocrates, the bench of Hippocrates, the cap of Hippocrates, the black disease of Hippocrates, the noise of the splashing of Hippocrates.

Consider them. The primary basis for the origin of the lexical phrase of Hippocrates is the oath «the ethical obligation that a doctor made in ancient Greece after graduation», was the "Asclepiades' oath», first recorded by Hippocrates, whose name is associated with an idea of the doctor's ethical behavior, and this tradition has been preserved to this day in student medical community, widely used in modern Russian language. Phraseologisms the face of Hippocrates or the mask of Hippocrates «facial expression of a person in a state of clinical death», «indifferent expression, inverted cheeks, sunken eyes, pale gray skin covered with drops of sweat» appeared on behalf of an ancient Greek doctor who described the clinical signs of death in his famous work «The Book of Foreknowledge». The lexical phrase of the fingers of Hippocrates, in medical terminology, is synonymous with drum fingers and is used in the meaning «deformation of the fingers in the form of a bulbous thickening of the terminal phalanges; observed in chronic diseases of the heart, lungs, liver».

The emergence of a lexical phrase of Hippocratic fingernail was the description by Hippocrates of the signs of nail deformation «deformation of the nails, in which the nail plates become in the middle part wider and convex, and the lateral and posterior ridges are raised; observed in the early stages of finger deformity as drum sticks». Phraseologism black disease Hippocrates or melena is named for Hippocrates, as he described the signs of a gastrointestinal disease: «(melaena; Greek melainanosos black disease, from melas, melanos dark, black; synonym.; Hippocrates black disease, tarry stool) - usually a sign gastrointestinal bleeding».

The history of the origin of the lexical phrase of the Hippocrates bench can be found in the Hippocrates work «On Joints», which describes the bench that was used in the treatment of various fractures and dislocations «a wooden bench with an inclined plane was used in the treatment of fractures; prototype of modern orthopedic tables». Hippocrates first described the methods of applying various dressings, in connection with this the expression Hippocrates hat appeared: «a bandage on the head, applied by a two-headed bandage; one part of the bandage is carried out from the forehead to the back of the head and back with radial rounds, grabbing each of them in a circular round of the second part of the bandage - through the forehead, back of the head and temporal fossa». 
The third group is significantly small in number, but in the medical terminological system plays a rather prominent role, as it is represented by commonly used expressions. These phraseologisms are borrowed from ancient Greek and Roman mythology, which are firmly incorporated into the medical terminological system. The peculiarity of the origin of mythical phraseological units in medicine is that they arose on the basis of similarity and association. Among metaphorical expressions, there are names of characters of ancient mythology, which are characterized by semantic transformation, convey other associative connections in medical terminology, which are based on mythological ideas about parts of human body. For example, in the Achilles tendon phraseology, reference is made to the legendary Greek hero Achilles. In the medical terminological system, the lexical phrase Achilles tendon is synonymous with the calcaneus tendon and means «the tendon of the triceps muscle of the leg attached to the tubercle of the calcaneus», in medicine it is considered a powerful tendon in the human body, but despite this it is the most commonly injured, therefore, a comparison is made with the mythical character Achilles, whose heel was vulnerable.

As it is known, phraseological combinations are able to undergo semantic changes, acquire new stylistic features, while their component composition and structure do not change. Basically, semantic changes occur in lexical phrases of a terminological nature, borrowed from mythical phraseological units. For example, the origin of phraseology Medusa's head is associated with the mythical monster «whose head is covered with wriggling snakes instead of hair», and in medicine, the lexical phrase Medusa's head is characterized by clear associative connections with the human organ «expansion of the saphenous veins of the anterior abdominal wall with serpentine branching around the navel; observed with portal hypertension». The name is given because in such cases, the veins around the navel, expanding, resemble the image of the head of the mythological Medusa - the most famous of the three Gorgon sisters, a monster with a female face, in which wriggling snakes instead of hair grew from the head.

Hercules disease, epilepsy, a chronic neurological disease of a person, manifested in the predisposition of the body to the sudden onset of convulsive attacks. The disease was named after Hercules - the hero of ancient Greek mythology, the son of the god Zeus and Alkmena. The Greeks believed that the mythical hero Hercules suffered from epilepsy. They believed that epilepsy was a form of obsession with spirits, but at the same time associated epileptic seizures with divine intervention.

The fourth small group is represented by biblical phraseological units. Biblical subjects and images that have become lexical phrases in medical phraseology cannot be understood unless their origin is known. The origin of the phraseology Adam's apple is associated with the legend of Adam, in whose throat the forbidden fruit was stuck. Phraseologism Adam's apple, which has become a medical term, has synonyms for the protrusion of the larynx, Adam's apple and is associated with a part of the human organ, in particular the larynx, and is recorded in the dictionary as follows: «protrusion of the larynx (prominentialaryngea; synonym: Adam's apple, Adam's apple) the upper part of the thyroid cartilage, forming an elevation on the front of the neck; in men is more developed».

In the medical phraseological fund, for example, phraseologism for the designation of chorea syndrome is noted: St. Witt's dance, a nervous disease, the same as chorea (a type of hyperkinesis), which manifests itself in rapid twitching of limbs, in winks, and smacking. Phraseologism of St. Witt's dance was associated with the legend of the cure of patients suffering from hysterical convulsions at the chapel of St. Witt of Zaberne in France.

Thus, on the basis of linguistic analysis, we have found that lexical phrases with anthroponyms are the most productive ways to replenish medical terminology. Anthroponyms as active components that make up lexical phrases reflect the history of medical science, which represents the heroes of ancient medicine, the names of scientists, doctors, who first described the phenomenon.

\section{References}

1 Энциклопедический словарь медицинских терминов: [В 3-х т.]. Около 60000 терминов / гл. ред. Б.В. Петровский. М.: Сов. энцикл., 1982-1984.

2 Кунин А.В. Курс фразеологии современного английского языка: учеб. пос. / А.В. Кунин. — М.: Изд. центр «Феникс», 1996. - 381 с.

3 Маслова В.А. Лингвокультурология: учеб. пос. для студ. высш. учеб. завед. / В.А. Маслова. — М.: Изд. центр «Академия», 2001. — 208 с. 


\title{
Ж.Ж. Шеризатова \\ Медициналық терминдердегі тұрақты тіркестердің
антропонимикалық компоненттермен берілуі
}

Мақала медициналық терминологиядағы тұрақты сөз тіркестерінің антропонимдік құрамдас бөліктерін талдауға арналған. Зерттеу пәні құрамдас бөлігінде антропонимдері бар медициналық фразеологиялық бірліктердің үлкен тобы. Негізгі назар құрылымдық, семантикалық және этимологиялық талдауға аударылды, антропонимдік компоненттері бар тұрақты тіркестердің негізгі тақырыптық топтары анықталды. Медициналық терминдерді қалыптастыруда қолданылатын тұрақты тіркестердің негізгі көздері мен модельдері анықталды. Жинақталған материал талданып отырған фразеологиялық бірліктердің құрамында синдром, симптом, ауру сөздері жиі кездеседі, олар медициналық фразеологизмдердің өзегі болып табылады деп айтуға мүмкіндік береді. Зат есімдегі тәуелді компонент антропониммен берілген, әдетте бұл медицина саласында маңызды жаңалық ашқан ғалымның есімі. Фразеологизмдердің бір бөлігі ретінде тиісті есімнің семантикасы мәселесіне көп көңіл бөлінеді. Зерттеліп жатқан материалды этимологиялық талдау негізінде тиісті компоненті бар медициналық фразеологиялық бірліктердің жіктелуі жасалды. Талдау көрсеткендей, тиісті атаумен фразеологиялық бірліктердің пайда болуы нақты тұлғаларға, ғалымдарға, ежелгі және библиялық мифологияға, кейіпкерлердің аттарымен байланысты әдеби шығармаларға негізделген. Лингвистикалық талдау үшін үлкен қызығушылықты ұлттық-мәдени ерекшеліктермен байланысты фразеологиялық комбинациялар үлкен қызығушылық тудырады. Зерттелген материалды дұрыс атау мәдени-ұлттық ақпаратты жеткізетін арнайы лингвистикалық белгі екенін көрсетті. Мақалада метафоралық түрде берілетін тұрақты тіркестер толығымен қарастырылған, терминологиялық жүйеде атаулардың метафоралық түрде ауысуы үнемі атап өтіледі, бұл белгілі сөздерді ғылыми қайта ойластыру арқылы жаңа атаулар мен медициналық терминдердің қалыптасуының тұрақты дамуымен байланысты.

Кілт сөздер: антропоним, фразеологиялық бірлік, компонент, синдром, белгі, медициналық терминология.

\author{
Ж.Ж. Шеризатова
}

\section{Устойчивые словосочетания с антропонимическими компонентами в медицинской терминологии}

\begin{abstract}
Статья посвящена анализу устойчивых словосочетаний с антропонимическими компонентами в медицинской терминологии. Предметом исследования стала многочисленная группа медицинских фразеологизмов, содержащих в своем компонентном составе антропонимы. Основное внимание сосредоточено на структурном, семантическом и этимологическом анализе, выделены основные тематические группы устойчивых словосочетаний с антропонимическими компонентами. Выявлены основные источники и модели устойчивых словосочетаний, используемые при формировании медицинских терминов. Собранный материал позволяет утверждать, что в составе анализируемых фразеологических единиц часто отмечаются слова «синдром», «симптом», «болезнь», которые являются структурным стержнем медицинских фразеологизмов. Зависимый компонент в именном словосочетании представлен антропонимом, как правило, это фамилия ученого, который сделал важные открытия в сфере медицины. Большое внимание уделено проблеме семантики имени собственного в составе фразеологической единицы. На основе этимологического анализа исследуемого материала разработана классификация медицинских фразеологических единиц с компонентом - именем собственным. Проведенный анализ показал, что в основе происхождения фразеологических единиц с именем собственным лежат реальные личности, ученые, античная и библейская мифология, литературные произведения, связанные с именами персонажей. Наибольший интерес для лингвистического анализа представляют фразеологические сочетания, связанные с национально-культурной спецификой. Исследованный материал показал, что имя собственное является особым языковым знаком, который несет в себе культурно-национальную информацию. В статье подробно рассмотрены устойчивые словосочетания, образованные путем метафорического переноса. Метафорический перенос наименований в терминологической системе отмечается регулярно, что обусловлено постоянным развитием образования новых наименований и значений медицинских терминов путем научного переосмысления общеизвестных слов.
\end{abstract}

Ключевые слова: антропоним, фразеологическая единица, компонент, синдром, симптом, медицинская терминология. 


\section{References}

1 Petrovsky, B.V. (Ed.). (1982-1984). Entsiklopedicheskii slovar meditsinskikh terminov. Okolo 60000 terminov [Encyclopedic dictionary of medical terms. About 60000 terms]. (Vols. 1-3). Moscow: Sovetskaiia entsiklopediia [in Russian].

2 Kunin, A.V. (1996). Kurs frazeolohii sovremennoho anhliiskoho yazyka [Modern English Phraseology Course]. Moscow: Izdatelskii tsentr «Feniks» [in Russian].

3 Maslova, V.I. (2001). Linhvokulturolohiia [Linguoculturology]. Moscow: Izdatelskii tsentr «Akademiia» [in Russian]. 